\title{
Erratum to: Network Control and Engineering for QoS, Security and Mobility II
}

\author{
Dominique Gaïti ${ }^{1}$, Guy Pujolle ${ }^{2}$, Ahmed Al-Naamany ${ }^{3}$, Hadj Bourdoucen ${ }^{3}$, \\ and Lazhar Khriji ${ }^{3}$ \\ 1 Université de Technologie Troyes, France \\ 2 Université Paris 6, France \\ 3 Sultan Qaboos University, Oman
}

\section{Erratum to:}

D. Gaïti et al. (Eds.)

Network Control and Engineering for QoS,

Security and Mobility II

DOI: $10.1007 / 978-0-387-35703-4$

The book was inadvertently published with an incorrect name of the copyright holder. The name of the copyright holder for this book is: (c) IFIP International Federation for Information Processing. The book has been updated with the changes. 